\title{
RESEARCH IN SPO
}

Exercise training-indu
proteins in canoeists

Autor(es): $\quad \begin{array}{ll}\text { Morawin, Barbara; Tylutka, Anna; Baumgarten, Maciej; Rynkiewicz, } \\ \text { Mateusz; Zembronacny, Agnieszka }\end{array}$

Publicado por: Imprensa da Universidade de Coimbra

URL

persistente:

URI:http://hdl.handle.net/10316.2/44120

DOI:

DOI:https://doi.org/10.14195/2182-7087_ex2018_57

Accessed : $\quad$ 26-Apr-2023 12:41:12

A navegação consulta e descarregamento dos títulos inseridos nas Bibliotecas Digitais UC Digitalis, UC Pombalina e UC Impactum, pressupõem a aceitação plena e sem reservas dos Termos e Condições de Uso destas Bibliotecas Digitais, disponíveis em https://digitalis.uc.pt/pt-pt/termos.

Conforme exposto nos referidos Termos e Condições de Uso, o descarregamento de títulos de acesso restrito requer uma licença válida de autorização devendo o utilizador aceder ao(s) documento(s) a partir de um endereço de IP da instituição detentora da supramencionada licença.

Ao utilizador é apenas permitido o descarregamento para uso pessoal, pelo que o emprego do(s) título(s) descarregado(s) para outro fim, designadamente comercial, carece de autorização do respetivo autor ou editor da obra.

$\mathrm{Na}$ medida em que todas as obras da UC Digitalis se encontram protegidas pelo Código do Direito de Autor e Direitos Conexos e demais legislação aplicável, toda a cópia, parcial ou total, deste documento, nos casos em que é legalmente admitida, deverá conter ou fazer-se acompanhar por este aviso. 


\section{ANNALS OF RESEARCH IN SPORT AND PHYSICAL ACTIVITY}




\section{EXERCISE TRAINING-INDUCED CHANGES IN INFLAMMATORY MEDIATORS AND HEAT SHOCK PROTEINS IN CANOEISTS}

Morawin Barbara'; Tylutka Anna1; Baumgarten Maciej²; Rynkiewicz Mateusz²; ZembronŁacny Agnieszka ${ }^{1}$

KEY WORDS: inflammation, cytokines, HSP27, HSP70, muscle damage

\section{INTRODUCTION}

According to cytokine overtraining theory, skeletal muscle injuries are related to systemic inflammatory reaction. In response to inflammation, cells rapidly produce a series of proteins known as heat shock proteins (HSPs). These are considered to be molecular chaperones which play a universal role in maintaining cellular homeostasis. Among the subset of stress-responsive proteins, HSP27 and HSP70 are considered to be a new approach to monitoring exercise training and adaptive mechanisms ${ }^{(1,2)}$. The study was designed to demonstrate the effect of sport training on changes in pro-inflammatory cytokines and HSPs, and their relation with muscle damage and body composition.

\section{MATERIALS AND METHODS}

Six elite canoeists $(19.8 \pm 2.9 \mathrm{yr})$ were observed during preparatory training period (March) at the 1st, the 4th and after 7 days of the conditioning camp, and then after 3 days of recovery.

\footnotetext{
1 Department of Applied and Clinical Physiology, Faculty of Medicine and Health Sciences, University of Zielona Gora, Poland.

2 Department of Sport and Health Promotion, Faculty of Medicine and Health Sciences, University of Zielona Gora, Poland.
}

Email: barbara.morawin@gmail.com 


\section{RESULTS}

The canoeing training did not induce muscle damage, decreased in IL-1 $\beta$ and HSP27, increased in TNF $\alpha$ and HSP70 concentrations. The highest changes in TNF $\alpha$ and HSP70 were observed 3 days after conditioning camp (during recovery) compared to initial level (the 1st day of conditioning camp). TNF $\alpha$ correlated with HSP27 ( $r=-0.563 ; \mathrm{P}<0.01)$ and HSP70 ( $r=$ $0.651 ; \mathrm{P}<0.001)$. Any significant changes in body composition were not observed.

\section{CONCLUSION}

These results show that 7-day canoeing training modulates pro-inflammatory response which is related to HSPs release into the circulation, and reveal that skeletal muscle damage is not necessary to induce training-induced inflammation.

\section{REFERENCES}

1. Banfi, G, Malavazos, A, Iorio, E, Dolci, A, Doneda, L, Verna, R, Corsi, MM 2006, Plasma oxidative stress biomarkers, nitric oxide and heat shock protein 70 in trained elite soccer players, European Journal of Applied Physiology, vol. 96, pp. 483-486.

2. Noble, EG, Milne, KJ, Melling, CWJ 2008, Heat shock proteins and exercise: a primer, Applied Physiology, Nutrition, and Metabolism, vol. 33, no. 5, pp. 1050-1065. 